Article

\title{
Sustainability in Higher Education: A Didactic Strategy for Environmental Mainstreaming
}

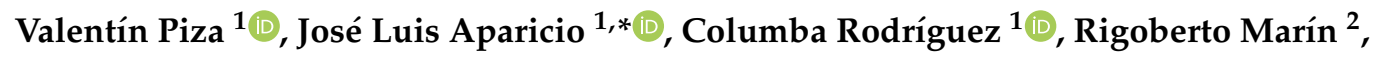 \\ Juana Beltrán ${ }^{3}$ and Ramón Bedolla ${ }^{4}$ \\ 1 Sciences for Regional Development Center-Autonomous University of Guerrero, Privada de Laurel 13, \\ Col. El Roble, Acapulco 39640, Guerrero, Mexico; vpiza@uagro.mx (V.P.); columba26@yahoo.com (C.R.) \\ 2 Autonomous University of Chihuahua, Ave. Universidad y Pascual Orozco s/n, \\ Chihuahua 31110, Chihuahua, Mexico; rimaur50@gmail.com \\ 3 Academic Unit of Nursing 1, Autonomous University of Guerrero, Chilpancingo 39000, Guerrero, Mexico; \\ rosas_gro@hotmail.com \\ 4 Academic Unit of Sociology, Autonomous University of Guerrero, Acapulco 39610, Guerrero, Mexico; \\ rabedsol@hotmail.com \\ * Correspondence: jlcoordinador@hotmail.com; Tel.: +52-744-207-7443
}

Received: 13 November 2018; Accepted: 29 November 2018; Published: 3 December 2018

\begin{abstract}
Institutions of higher education play a fundamental role in the effort to reach sustainability; there are different ways to achieve it. The objective of this work carried out in 2017 was to design, implement and evaluate a course-workshop that will provide teachers of the Bachelor's Degree in Accounting and Administration at the Autonomous University of Guerrero (UAGro) tools to incorporate the environmental axis into their learning unit programs, in the context of environmental education. It was a study with a qualitative and transversal approach, based on constructivism and transversality. It was structured with its foundation in institutional documents. The design and selection of the themes was carried out in conjunction with a team of experts. Twenty-four teachers participated. The initial and final evaluation was carried out through guiding questions and surveys; the initial result showed an economistic vision of the environment, as well as ignorance about strategies to incorporate the environment as one of the dimensions of sustainability; this contrasts with the final evaluation, in which knowledge and willingness to incorporate the environment into their respective learning unit programs was observed, as well as satisfaction with the course-workshop that had developed. It is concluded that it is necessary to strengthen the processes of teacher training and give continuity to them for the incorporation of the environment as a contribution to sustainability.
\end{abstract}

Keywords: sustainability; higher education; sustainability

\section{Introduction}

\subsection{The Environmental Problem}

The concern for the environmental condition has always existed, but it was strengthened in the twilight of the sixties and early seventies. International organizations focused their attention on this problem (pollution, deforestation and the greenhouse effect, among others); this is the case of the Club of Rome, which in 1968 made recommendations to face it. This highlights a first approach to combine environmental and educational themes in order to generate awareness and modify patterns of behavior [1]. In 1972 in Stockholm, Sweden, the birth of Environmental Education (EE) was formally considered, since the education system was given responsibility for the formation and generation of knowledge to generate environmental awareness. Two subsequent events reinforced this proposal, 
in 1973, the creation of the International Program of Environmental Education, and in 1977, in Tbilisi, Georgia, the Intergovernmental Conference on Environmental Education [2].

There was significant progress with the presentation of the Action Plan for Sustainable Development in Higher Education Institutions [3], which pointed out the urgent need to incorporate environmental content in all academic programs, in order to contribute to the generation of a culture of sustainability and the construction of a minimum knowledge base in that field. The final Declaration of the World Conference on Higher Education [4] established that, for the training of ethical citizens, promoters of critical thinking and active citizenship that will contribute to sustainability, peace and social well-being, universities should provide solid competences to their graduates.

These competences are integral actions to identify, interpret, argue and solve problems; they can be academic, work and professional and should be oriented to meaningful learning, taking into account the context; and they are the result of an integration process and should be associated with execution criteria $[5,6]$.

In order to develop these competences and influence environmental training for sustainability, it is necessary to generate changes, which focus on the need to address emerging issues from the curriculum, such as the environment, gender, poverty and justice, among others. Lingren et al. [7] mention that, if university graduates do not contribute enough to sustainability, it is due to the lack of awareness and disposition, which is the result of the lack of inclusion of these environmental contents in study plans.

In 2015, the United Nations presented the 2030 Agenda for Sustainable Development (SD), in which it set out 17 objectives, the result of public consultations with government agencies and civil associations. The number 4 corresponds to a quality education; in its goals it establishes that through education for the sustainable development, it is guaranteed that the students obtain competences to foment it; in addition, it declares the importance of training, particularly in countries of emerging economies, to increase the number of qualified teaching staff [8].

\subsection{Incorporation of the Environment and Sustainability in Higher Education}

In the search for sustainability, in several countries work is being done so that higher education institutions incorporate to their substantive functions aspects related to the environment as an emerging social issue [9]. A study conducted in Malaysia reports the great challenges that this implies which, among others, include a greater participation of governments, as well as non-governmental organizations. The importance of university research as a generator of information for decision making is highlighted [10]. A study carried out in Brazil, agrees that universities initiate their processes towards sustainability with the strengthening of research, but without ceasing to attend to teaching [11].

Higher education institutions, and within them universities, are fundamental for society to achieve sustainability [12]. It needs to be an example to follow; this is the case in those that work to be considered as "sustainable universities", a concept that defines educational institutions that with micro and macro actions aim at mitigating the consequences that derive from the exercise of their substantive functions [13].

Leal Filho [14] considers that few universities have been successful, especially due to the mishandling of concepts, which limits their true use. An international survey, applied to 600 universities, found in the answers that the subject is abstract and distant from reality. He argues that in order to substantially improve the approach to sustainability, it is necessary to address formation and personnel training.

Attempts to integrate the environment into the subjects as part of sustainability are not new. In Colombia, through a case study, their level of incorporation was evaluated in some higher education institutions [15]. Another study also conducted in Colombia, focused on detecting strengths and weaknesses, regarding its inclusion in architecture programs [16]. In Mexico, a methodological proposal was made to diagnose environmental presence (at the axis level) in higher level educational programs [17]. 
In Spain, the University of Girona developed a Guide for the Adaptation to the European Higher Education Area, with a focus on sustainability, considering that this concept, already present in different areas, could not be alien to education [18]. In Honduras, a guide was prepared to incorporate the environment, with emphasis on energy efficiency, taking the Business Engineering degree as a pilot experience [19].

Similar studies analyze the pending tasks to achieve the full incorporation of the environment. Among others, we can mention training strategies for teachers, as well as the promotion of research processes [20]. Other proposals focus on the generation of conceptual change, institutional openness or curricular flexibility $[16,21]$, that is to say, with diverse strategies and particularities. However, they all seek that the environmental issue be incorporated in the integral formation of the student. Incorporating the environmental issue into the functions of higher education institutions, in their administrative functions or in student training, with a focus on sustainability, requires various strategies to clarify tasks to help achieve institutional purposes. In the case of incorporation into the student's training processes, transversality is presented as a good didactic strategy, since it allows the disciplines to be connected with emerging themes such as the environment [22]. For Fuentes et al. [23] it is a complement to the disciplinary teaching, since it is transversal. It represents a possibility to transform the current paradigm towards a more globalizing one [24].

Transversality develops emerging social themes through axes, incorporated in curricular areas; they integrate being, doing, knowing and living together, and operate in an interdisciplinary and interdisciplinary way [25]. The transverse axis environment stands out, referring to the study of the interrelation of air, water, soil and ecosystems, in a SD framework [17]. In sum, we can say that transversality is a strategy consistent with the characteristics and purposes of environmental mainstreaming [19,26-28].

For Gavidia [29] a strategy to achieve transversality is through the construction of "spaces", referring to the execution of subjects or short-term studies, to allow the coexistence of the discipline with the approach of a topic.

Clavijo [30] states that in the 21st century there is a significant change in the way students assume the search for knowledge, and notes that the educational process is more complex and dynamic. The university teacher faces in the classroom the consequences of a changing world, product of globalization, technology and communications which, today more than ever, must dominate the didactics of each profession, understood as the special approach for each discipline. This depends directly on two fields of knowledge: the sciences of education and an area of knowledge or discipline [31].

It is necessary that the teacher knows how to plan, organize, manage and implement innovative and creative processes that generate in the student the desire to be part of it [32]. For this reason, the construction of a subject plan becomes more relevant; realizing it involves, among other things: (a) knowing in depth the history and epistemology of the theories and concepts to be taught; (b) know how to sequence objectives and contents of the curriculum, disciplines, generic and cross-cutting as the environment; (c) taking into account the interests, ideas and daily arguments of the students in what is to be developed, as well as the main difficulties and obstacles; (d) applying teaching strategies such as transversality that help in the learning process; (e) preparing suitable materials for the implementation of the sequence; (f) knowing how to manage or direct the implementation of the competence or didactic sequence; and (g) continuously evaluating the teaching-learning process [31].

\subsection{Research Context}

The Autonomous University of Guerrero (UAGro) is the main educational institution in the state of Guerrero and has an enrollment of 89,300 students. The city of Acapulco concentrates $28.5 \%$ of this population [33]. Its Educational Model [34] is based on the constructivist approach, and has among its guiding axes sustainability. It raises the importance of addressing various cross-cutting issues in the classroom, including the environment. Moreno [31] shares a proposal in accordance with that of the institution. 
One of the institutional documents of the UAGro is the learning unit program [35], which integrates the curricular elements of the study plan that must be implemented in the student learning process. It consists of eight elements: (1) identification; locates the learning unit program in the curricular context: educational program; area of knowledge; modality (face-to-face, blended or distance learning); training stage (institutional, professional or integration and linking); learning unit program-background, recommended prerequisites; credits; and number of hours; (2) contribution to the graduation profile; (3) competence, disaggregated in knowledge, skills and attitudes; (4) pedagogical-didactic orientations; (5) synthesis of the didactic sequences that make up the program; (6) learning resources; (7) profile and teaching competences; and (8) evaluation criteria for teaching competences.

Undoubtedly, literature on competencies, education and the environment, as well as on sustainability, is very vast. Multiple theorists analyze profusely what is understood by these educational topics, as well as the so-called "emerging social" themes. In the same way, the theorists take the time to explain why it should be included in the curriculum. However, what they have written about how it can and should be done is very limited. This proposal presents an implementation strategy, which not only breaks it down in the Bachelor's Degree, but goes further and with the participation of a group of higher education teachers. It is able to raise it in a specific and objective way in the program of learning unit program, according to the institutional regulations of the UAGro.

For this research, the Bachelor's Degree in Accounting and Administration of the UAGro was contemplated, since its curriculum was in the process of being updated, it was one of the three educational programs with the highest enrollment at the state level (2000) and the teachers showed willingness to participate in the research process.

The objective of this work was to design a learning unit program through teacher training, incorporating the environment axis, through the transversality strategy.

The research has a qualitative approach [36]. It was transversal and based on socio-constructivism.

\section{Materials and Methods}

A diagnosis of training needs was first undertaken to know the topics that were of interest to teachers, resulting in three: environment, transversality and teaching skills. Then, together with a team of experts, the course-workshop called: Incorporation of the environment, was designed through the strategy of mainstreaming. It was structured with a foundation in the design of learning unit programs and in the process of Design, Evaluation and Updating of Bachelor's Study Plans [35] and lasted $18 \mathrm{~h}$. The implementation was made in 2017, in Bachelor's Degree in Accounting, the Faculty of Accounting and Administration of the UAGro. For the development of the course-workshop, a competence was proposed: to incorporate orientations of the environmental axis in its learning unit (LU) program, through the strategy of transversality, to strengthen the integral formation of the student, based on collaborative work.

- Knowledge. To understand EE conceptually; to know the strategies for the incorporation of transversal axes; to identify elements of the environmental axis that can be incorporated into the LU program.

- Skills. To identify the basic concepts of EE; to use didactic strategies for transversality in their learning unit program; to incorporate elements of the environment axis into the LU program.

- Attitudes and Values. To promote collaborative work.

The first part was introductory and included sessions one and two; the objective was for teachers to understand EE and to know the strategies for their incorporation through transversal axes. For this, $12 \mathrm{~h}$ were allocated. The second part was carried out in session three and consisted in putting learning into practice; the teachers were invited to identify those elements of the environmental axis that were feasible to be incorporated in their learning unit program. This phase lasted $6 \mathrm{~h}$. As a final product, the participants were asked to elaborate the LU program, with orientations for the incorporation of the environment axis, through the strategy of transversality. 
To measure the knowledge, skills and attitudes acquired, as well as the degree of satisfaction of teachers with the development of the course-workshop, three instruments were applied; the first was used to assess the teaching learning at the beginning of the training process, through guiding questions:

1. What is sustainability?

2. What is the strategy of transversality?

3. How can the emerging social issues be addressed?

4. How does transversality contribute to the integral formation of the student?

5. What is your opinion about your educational program and subject plan?

6. What do you think about the fact that all teachers must join the Curriculum Design Committee?

The second instrument was built according to the proposals of UAGro, Chile's Ministry of Education, Yus and Molina [34,37-39], and consisted of a survey that assessed the learning achieved by the participants at the end of the course-workshop. Fifteen items were structured, with a nominal scale of measurement (yes, no, do not know) around the topics of the course-workshop:

\subsection{Environmental Education for Sustainability}

1. The environment is a system formed by natural and artificial elements, interrelated and modified by human action.

2. Environmental impact is the alteration of the environment caused, directly or indirectly, by a project or activity in a certain area.

3. Environmental education is a permanent interdisciplinary process aimed at the formation of a citizenship that recognizes values, clarifies concepts and develops the skills and attitudes necessary for a harmonious coexistence between human beings, culture and biophysical environment.

4. Sustainable development (SD) is the process of sustained and equitable improvement of people's quality of life, through appropriate measures of conservation and protection of the environment, so as not to compromise the expectations of future generations.

5. Addressing environmental deterioration and contributing to the preservation of resources must be a shared responsibility.

\subsection{Transversality Strategy}

6. The transversality is a strategy to understand and addressing emerging issues of social relevance, contributing to the comprehensive training of students, with the development of skills to analyze, criticize and improve the reality of their context.

7. Emerging and socially relevant issues such as the environment are not disciplinary and are established through axes that cross the curriculum of a study plan.

8. Transversal axes imply an approach to daily life and contextualize the contents through real situations.

9. The environmental axis must be incorporated into all categories of the population, including socio-professional, scientific and technical, having its disciplines and activities relationship and impact on the environment.

10. Mainstreaming is a process of inclusion of an axis that crosses the entire study plan.

\subsection{Teaching Competences}

11. The humanistic formation is centered in the person, it is integral, propositive, pertinent and contextualized.

12. Generic competences are those that all professionals must develop to understand their environment and try to transform it.

13. The specific competences are those that are applied in the performance corresponding to the professional profile and exercise of each discipline. 
14. The writing of a competence should take into account the following aspects: the verb of performance, the object of knowledge, the condition of quality, the purpose, the context and the value to acquire.

15. The education offered by the UAGro is training based on social constructivism, committed to the environment with $\mathrm{SD}$, and is guided by its responsibility towards society.

The third instrument was a survey to assess the degree of satisfaction with the course-workshop, using a measurement scale: satisfied, slightly satisfied and not satisfied. The aspects to be evaluated were structured based on five components: planning, activities developed, execution, facilitator performance and general evaluation.

The administrative authorities of the Faculty of Accounting and Administration invited the 60 teachers of the educational program staff to the course-workshop; 24 participated voluntarily. To develop the activities planned, five work teams were integrated.

In order to prepare the learning unit program, the UAGro institutional format was used so that teachers would identify the competences to be developed. The final product was the elaboration of its LU program that is presented as an example in the Section 3.

\section{Results}

The results of the evaluations made to the teachers during the implementation of the course-workshop are detailed below.

\subsection{Assessment of Teaching Knowledge at the Beginning of the Course-Workshop}

The evaluation applied at the beginning of the course-workshop allowed participants to understand the perception that they had with respect to sustainability. There were those who had an economistic vision when considering it as "economic profit of the companies"; others who were more conservationist saw it as "an awareness of the future of society." Regarding SD, in general it was conceptualized as an improvement, equitable with the quality of life of the people and generator of appropriate measures for the conservation and protection of the environment; it seeks not to compromise the future of the next generations. They concluded that there are emerging issues of social relevance that cannot be considered as disciplinary, and that their correct approach contributes in the formation of competencies for the analysis and improvement of their reality, as well as in the integral formation of the student.

Likewise, they recognized transversality as a didactic strategy, an integral approach, and a way of approaching and identifying aspects that permeates the context and affects the student's education. They considered that, from the stage of institutional formation, during or at the end of each LU, issues on the importance of the environment should be incorporated, as well as be considered in the development of socio-professional, scientific and technical competences at all educational levels, especially the higher level.

In the program and the DS as class instruments, it was found that most of the competences are not oriented to each LU; they have repetitive content or there are programs without respective sequences. This was due to the fact that there are teachers who do not attend the courses or participate in their respective curricular design committees. It is necessary to design strategies so that all are incorporated.

\subsection{Learning Evaluation}

About the EE, the teachers agreed to consider it as "a process of interdisciplinary nature, permanent and aimed at the formation of a citizenship with values, which develops knowledge, skills and attitudes for a healthy coexistence between people, culture and biophysical environment".

In the analysis of the educational program, they agreed that education offered by UAGro is based on social constructivism, committed to the SD and guided by its responsibility towards society. It is humanistic, centered on the person and on learning, integral, purposeful, pertinent and contextualized. 


\subsection{Evaluation of the Degree of Satisfaction of the Course-Workshop}

At the end of the course-workshop, a survey was applied to assess the degree of teacher satisfaction with the following areas: planning, activities developed, execution, facilitator performance and knowledge evaluation. The teachers showed total satisfaction with each of the stages of the updating process.

\subsection{Environmental Mainstreaming}

With the learning obtained in the training, and with the necessary orientations, teachers designed a learning unit program with the incorporation of the environmental axis through the transversality strategy, according to the elements of the UAGro institutional format. As an example, a program for the subject of Marketing III is presented (Tables 1 and 2 and Figure 1).

- Learning resources: textbooks and articles from specialized journals in marketing.

- Profile and teaching competences: bachelor's degree in administration, master's degree and/or specialty in marketing; and constant updating of courses and diplomas. Professional and teaching experience, minimum of three years. This adapts to the teaching competences required by the institution.

- Criteria for evaluating teaching competencies: these adapt to the processes of institutional evaluation.

Table 1. Environmental transversality: marketing program III.

\begin{tabular}{|c|c|c|c|}
\hline & Identification & & Contribution to the Graduation Profile \\
\hline $\begin{array}{l}\text { Learning unit: } \\
\text { Marketing III } \\
\text { Bachelor Program in } \\
\text { Accounting and } \\
\text { Administration } \\
\text { Specific professional } \\
\text { training stage } \\
6 \text { credits } \\
96 \mathrm{~h} \\
\text { Face-to-face modality }\end{array}$ & $\begin{array}{l}\text { Learning units } \\
\text { backgrounds: Marketing } \\
\text { I and Marketing II }\end{array}$ & $\begin{array}{l}\text { Recommended prerequisite } \\
\text { skills: text comprehension, } \\
\text { collaborative work, } \\
\text { leadership, ICT proficiency, } \\
\text { English comprehension. }\end{array}$ & $\begin{array}{l}\text { This learning unit contributes to generating } \\
\text { a commitment to society and its } \\
\text { environment, applying the strategies and } \\
\text { current trends in marketing. }\end{array}$ \\
\hline
\end{tabular}

Table 2. Synthesis of the didactic sequences that make up the marketing III program.

\begin{tabular}{lcccc}
\multicolumn{1}{c}{ Competence's Element } & Sessions & $\begin{array}{c}\text { Hours with the } \\
\text { Facilitator }\end{array}$ & $\begin{array}{c}\text { Independent } \\
\text { Hours }\end{array}$ & $\begin{array}{c}\text { Total } \\
\text { Hours }\end{array}$ \\
\hline $\begin{array}{l}\text { To use technological tools to graphically describe the } \\
\text { evolution of marketing. }\end{array}$ & 4 & 16 & 4 & 20 \\
\hline $\begin{array}{l}\text { To analyze critically with reference to prior } \\
\text { knowledge of marketing strategies }\end{array}$ & 4 & 16 & 4 & 20 \\
\hline $\begin{array}{l}\text { To create social marketing campaigns applied to } \\
\text { their local environment with social responsibility } \\
\text { and respect for the environment, with the purpose of } \\
\text { addressing some of the current social problems. }\end{array}$ & 8 & 32 & 24 & 56 \\
\hline \multicolumn{1}{c}{ Total } & 16 & 64 & 32 & 96 \\
\hline
\end{tabular}

According to the didactic and pedagogical orientations of the UAGro, the next step for the teachers who elaborated this LU program is to build their class plan, where they integrate didactic strategies to develop the competence and where the mainstreaming of the environment is reflected, as a contribution to sustainability. 


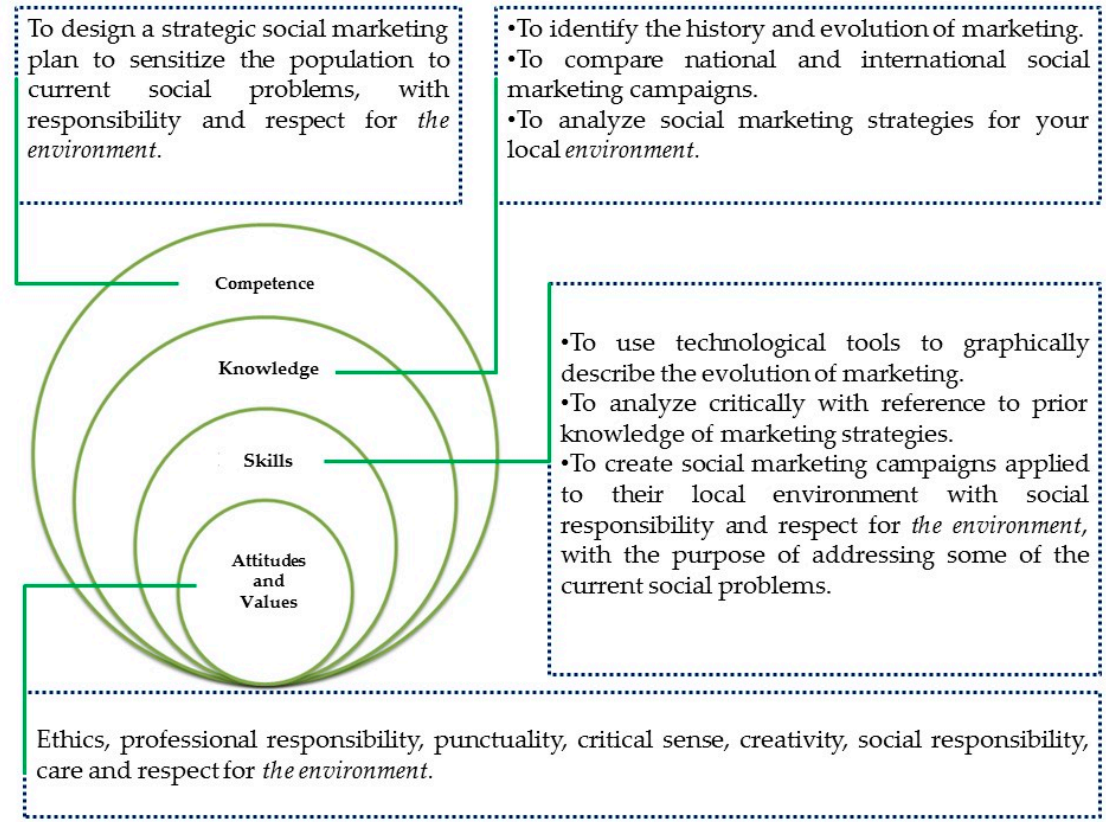

Figure 1. Environmental transversality: marketing III competence.

\section{Discussion}

The results obtained for the incorporation of the environment in higher education allow us to propose three ideas that guide the discussion:

\subsection{Conceptualization of Environmental Education, Sustainability and Transversality}

Previous knowledge of the teaching staff was varied. The conception of EE integrates physical, social and cultural elements, with a focus on competency-based education. Sustainability is a term with more complexity. The economist vision is justified by his business training; in the case of conservationist responses, they agree that it is about the use of natural resources; it is striking that they do not consider the environmental, social and economic dimensions in an integrated manner. This heterogeneity of thought is not exclusive to UAGro in Mexico; Bullock and Hitzhusen [40] used participatory development methods to explore the successes and challenges of sustainability in the state of Ohio, in the United States of America and interviewed 20 university leaders to produce concepts of sustainability. They discovered that it is a complex word and that it is difficult to reach a general definition. The authors suggest strengthening the essential concepts of sustainability. Sometimes there is not only a diversity of answers, but an erroneous management that becomes a limitation for the growth of universities [14].

On the strategy of transversality, UAGro teachers did not doubt its usefulness for the training of students. They also identified areas of opportunity to incorporate environmental issues in a transversal way in their learning unit program. At the end of the training, an apprenticeship in the subject was obtained. They refer to transversality as a process that crosses the curriculum to include non-disciplinary topics of social relevance; this idea is in accordance with the approach of [22]. The foregoing is indicative that the processes of teacher training must be continuous to advance education for sustainability. On the above, Bertschy, Künzli and Lehmann [41] presented in Switzerland two models for their implementation in teacher training and education for sustainable development. They refer to the fact that a teacher needs disciplinary and pedagogical knowledge for the implementation of the SD; however, the structure does not allow it, which is why interdisciplinarity is necessary. As can be noted, Moreno [31] is in tune with this idea, raises the need for a specific didactic and disciplinary knowledge. 
Hassanpour, Alpar and Ghaderi [42] developed a case study in Turkey to incorporate sustainability into architectural education. They analyzed descriptions of the courses, the teaching methods and the perceptions of teachers and students about the incorporation of sustainability. They found that adding a course to compensate for the lack of sustainability "is controversial" and goes against the curricular genesis. They affirm that courses must have environmental, social, economic and cultural themes. Its incorporation should be gradual: sensitize in the first year, advance in understanding between the second and third year and end with the development of the competition. Sustainability must be integrated horizontally and vertically.

\subsection{Teacher Awareness}

In the research progress was made in teacher sensitization and awareness; at the end of the training, there was not only a disciplinary and pedagogical apprenticeship, but a change of attitude, favorable to incorporating environmental issues into the curriculum, which allows progress towards sustainability. A similar result was obtained by Hamiti and Wydler [43] who developed a research to discuss sustainability in the educational programs at the University of Applied Sciences in Zurich. They managed to reduce resistance and sensitize teachers and students. In 2010, this university was recognized for contributing to the "United Nations World Decade for Education for Sustainable Development in Switzerland". The administration of the school has valued the importance of the activity and has encouraged the working group to continue with the awareness process, especially those teachers who still work marginally on sustainability. This successful experience could be replicated in the UAGro.

\subsection{Didactic Proposal Derived from Training}

There are different ways to incorporate the environment in higher education. In this case, some teachers were able to build a LU program, which Moreno [31] calls applying strategies in the learning process and managing the implementation of a competition. In an experience in Barcelona, Spain, Albareda-Tiana, Vidal-Raméntol, Pujol-Valls and Fernández-Morilla [44] documented project-oriented learning and an interdisciplinary workshop on sustainable foods, for the development of competencies involving 23 students in pre-service teacher training. They concluded that it is an "excellent methodology" focused on the student that allows for their empowerment and mobilization in the implementation of the objectives for the SD in the university. In the literature mentioned above, there are other experiences that range from a conceptual understanding to the incorporation of a subject or teacher training $[16,20,21]$. It remains to give continuity to the process of teacher education and training, as well as to explore new ways to incorporate the environment into the higher education, aimed at achieving sustainability.

\section{Conclusions}

The design and implementation of the course-workshop achieved the task of reinforcing teaching competencies by articulating environmental issues with methodological strategies for their incorporation, such as curricular design and transversality strategy.

Volunteer participants in the teachers' workshop course showed interest in participating in training and updating processes, as well as a commitment to the profession and to their students.

The initial and final evaluations served to verify that the competence of the course-workshop was relevant, contributed to the increase of their knowledge, the development of their skills, and awareness in relation to environmental transversality.

In the subjects related to the environment, it is very important to consider what or how to incorporate them from the curricular design, but it is also convenient to close the process by defining how to achieve it, to arrive at concrete and evaluable results that lead to the strengthening of a comprehensive education of the student. 
Author Contributions: V.P. conceived the original idea of the research, and participated in the elaboration of the methodology and in determining the state of the art; J.L.A. collaborated in the elaboration of the state of the art, the theoretical framework and the conclusions; C.R. participated in the discussion of the results; R.M., J.B. and R.B. collaborated in the analysis of results. All the authors participated in the review and final writing of the article.

Funding: This research received no external funding.

Acknowledgments: We thank the group of teachers participating in the Bachelor's Degree in Accounting and Administration of the UAGro, in particular Master Evelyn Zavaleta for allowing us to publish her LU program in this research; we also recognize the technical orientation of Rosa María Brito.

Conflicts of Interest: The authors declare no conflict of interest.

\section{References}

1. Zabala, I.; García, M. Historia de la Educación Ambiental desde su discusión y análisis en los congresos internacionales. Rev. Investig. 2008, 32, 201-218.

2. Caride, J.A. La Educación Ambiental en las Universidades y la Enseñanza Superior: Viejas y nuevas perspectivas para la acción en clave de futuro. In Proceedings of the Conferencias del V Congreso Iberoamericano de Educación Ambiental, Joinville, Brazil, 2 November 2006; pp. 429-442.

3. Asociación Nacional de Universidades e Instituciones de Educación Superior-Secretaría de Medio Ambiente y Recursos Naturales. Plan de Acción Para el Desarrollo Sustentable en las Instituciones de Educación Superior; ANUIES: México DF, Mexico, 2000. Available online: http://www.complexus.org.mx/Documentos/ ANUIES-PlandeAccionSemarnat.pdf (accessed on 4 July 2018).

4. United Nations Educational, Scientific and Cultural Organization. Conferencia Mundial Sobre la Educación Superior: La Nueva Dinámica de la Educación Superior y la Investigación Para el Cambio Social y el Desarrollo. 2009. Available online: http:/ / www.unesco.org/education/WCHE2009/comunicado_es.pdf (accessed on 13 October 2018).

5. Tobón, S. Metodología de Gestión Curricular. In Una Perspectiva Socioformativa, 1st ed.; Trillas: México, Mexico, 2013; ISBN 9786071715333.

6. Aguerrondo, I. Conocimiento Complejo y Competencias Educativas; Working Papers on Curriculum Issues, N. 8; IBE/UNESCO: Ginebra, Suiza, 2009. Available online: http:/ /www.ibe.unesco.org/fileadmin/user_upload/ Publications/Working_Papers/knowledge_compet_ibewpci_8.pdf (accessed on 24 September 2018).

7. Lindgren, A.; Rodhe, H.; Huisingh, D. A sistematyc approach to incorporate sustainability into university courses and curricula. J. Clean. Prod. 2006, 14, 797-809. [CrossRef]

8. Organización de las Naciones Unidas. Agenda 2030 y los objetivos de Desarrollo Sostenible. In Una Oportunidad Para América Latina y el Caribe; ONU-CEPAL: Santiago de Chile, Chile, 2016.

9. Brito, R.M.; Rodríguez, C.; Aparicio, J.L.; Paolacci, J.; Sampedro, M.L.; Beltrán, J. Indicators of Sustainability in Educational Practice: Perception of Teachers and Students of UAGro-Mexico. Sustainability 2018, 10, 3733. [CrossRef]

10. Foo, K.Y. A vision on the role of environmental higher education contributing to the sustainable development in Malaysia. J. Clean. Prod. 2013, 15, 6-12. [CrossRef]

11. Jabbour, C.J.; Sarkis, J.; De Sousa, A.B.; Govindan, K. Understanding the process of greening of Brazilian business schools. J. Clean. Prod. 2013, 61, 25-35. [CrossRef]

12. Wang, Y.; Shi, H.; Sun, M.; Huisingh, D.; Hansson, L.; Wang, R. Moving towards an ecologically sound society? Starting from green universities and environmental higher education. J. Clean. Prod. 2013, 61, 1-5. [CrossRef]

13. Velázquez, L.; Munguia, N.; Platt, A.; Taddei, J. Sustainable University: What can be the matter? J. Clean. Prod. 2006, 14, 810-819. [CrossRef]

14. Leal Fhilo, W. About the Role of Universities and Their Contribution to Sustainable Development. High. Educ. Policy 2011, 24, 427-438. [CrossRef]

15. Gómez, C.; Botero, C. La Ambientalización de la Educación Superior: Estudio de caso en tres instituciones de Medellín, Colombia. Rev. Gest. Ambient. 2012, 15, 77-88.

16. Restrepo, C. Greening Curriculums, in a Sustainable Frame, in the Architecture Programs at Colombian's Coffee Area's Universities. Master's Thesis, Universidad Nacional de Colombia, Manizales, Colombia, 2014. 
17. Aparicio, J.L.; Rodríguez, C.; Beltrán, J.; Sampedro, L. Metodología para la transversalidad del eje medio ambiente. Rev. Iberoam. Cienc. Soc. Humaníst. 2014, 3, 163-172.

18. Universidad de Girona. Guía para la Adaptación al Espacio Europeo de Educación Superior 10. In Competencias Transversales: Sostenibilidad; Universidad de Girona: Girona, España, 2010. Available online: http:/ / www.udg.edu/portals/9/publicacions/guieseee/guia10_v3_esp.pdf (accessed on 12 October 2018).

19. International Resources Group. Guía Para Transversalizar el eje Ambiental en las Carreras del Nivel de Educación Superior de Honduras; IRG: Tegucigalpa, Honduras, 2009. Available online: http:/ / www.mirahonduras.org/ publicaciones/Guia_transv_eje_amb_universidades(9_2009).pdf (accessed on 10 September 2018).

20. Velásquez, J.A. La transversalidad como posibilidad curricular desde la educación ambiental. Rev. Latinoam. Estud. Educ. 2009, 5, 29-44.

21. González, E. La Transversalidad de la Educación Ambiental en el Currículum de la Enseñanza Básica; CENEAM: Guadalajara, México, 2000. Available online: http://www.magrama.gob.es/es/ceneam/articulos-deopinion/2000-edgar-gonzalez_tcm7-180887.pdf (accessed on 4 July 2018).

22. Díaz, F. Curriculum research and development in Mexico: The presidential address, 2004. J. Am. Assoc. Adv. Curric. Stud. 2010, 1, 1-24.

23. Fuentes, L.; Calderas, Y.; Mendoza, I. La transversalidad curricular y la enseñanza de la educación ambiental. Rev. Cient. Cienc. Humanas 2006, 2, 39-59.

24. Bravo, E. La Transversalidad Como vía Para la Formación Integral. Ph.D. Thesis, Universidad de Zulia, Maracaibo, Venezuela, 2005.

25. Botero, C.A. Los ejes transversales como instrumento pedagógico para la formación de valores. Rev. Iberoam. Educ. 2008, 3, 49-59.

26. Muñoz, V.J.M. La educación ambiental como eje transversal en el currículo. Rev. Innovación Exp. Educ. 2010, 29, 1-9.

27. Magendzo, A. Currículo y transversalidad una reflexión desde la práctica. Rev. Int. Magisterio 2005, 1, 28-33.

28. González, M.D.C. Principales tendencias y modelos de la educación ambiental en el sistema escolar. Rev. Iberoam. Educ. 1996, 11, 13-74.

29. Gavidia, V. La transversalidad y la escuela promotora de salud. Rev. Esp. Salud Públ. 2001, 75, 505-516. [CrossRef]

30. Clavijo, D. Competencia del docente universitario en el siglo XXI. Rev. Esp. 2018, 39, 20.

31. Moreno, T. Didáctica de la Educación Superior: Nuevos desafíos en el siglo XXI. Rev. Perspect. Educ. 2011, 50, 26-54.

32. Árias, M.D.L.; Arias, J.; Ortiz, M.M.; Garza, M.G. Perfil y competencias del docente universitario recomendados por la UNESCO y la OCDE. Rev. Atlante Cuad. Educ. Desarro. 2018. Available online: https: / www.eumed.net/rev/atlante/2018/06/competencias-docente-universitario.html/ / hdl. handle.net/20.500.11763/atlante1806competencias-docente-universitario (accessed on 22 October 2018).

33. Universidad Autónoma de Guerrero. Anuario Estadístico 2017-2018; Universidad Autónoma de Guerrero: Chilpancingo, Mexico, 2018.

34. Universidad Autónoma de Guerrero. Modelo Educativo, Special ed.; Gaceta Universitaria; Universidad Autónoma de Guerrero: Chilpancingo, Mexico, 2013.

35. Universidad Autónoma de Guerrero. Diseño, Evaluación y Actualización de Planes de Estudio de Licenciatura (en el Marco del Modelo Educativo y Académico de la UAG); Universidad Autónoma de Guerrero: Chilpancingo, Mexico, 2012.

36. Hernández, R.; Fernández, C.; Baptista, P. Metodología de la Investigación, 4th ed.; Mc Graw-Hill: México DF, Mexico, 2014.

37. Ministerio de Educación de Chile (MINEDUC). Cómo Llegamos a ser una Comunidad Educativa Sustentable: Educación Para el Desarrollo Sustentable; MINEDUC: Santiago de Chile, Chile, 2013.

38. Yus, R. Temas Transversales: Hacia una Nueva Escuela; Graó, Ed.; Graó: Barcelona, España, 1998.

39. Molina, D. Ejes transversales en el currículo universitario: Experiencia en la carrera de derecho. Ciênc. Cognição 2007, 10, 132-146.

40. Bullock, C.; Hitzhusen, G. Participatory Development of Key Sustainability Concepts for Dialogue and Curricula at the Ohio State University. Sustainability 2015, 7, 14063-14091. [CrossRef]

41. Bertschy, F.; Künzli, C.; Lehmann, M. Teachers' Competencies for the Implementation of Educational Offers in the Field of Education for Sustainable Development. Sustainability 2013, 5, 5067-5080. [CrossRef] 
42. Hassanpour, B.; Alpar Atun, R.; Ghaderi, S. From Words to Action: Incorporation of Sustainability in Architectural Education. Sustainability 2017, 9, 1790. [CrossRef]

43. Hamiti, S.W.; Wydler, H. Supporting the Integration of Sustainability into Higher Education Curricula-A Case Study from Switzerland. Sustainability 2014, 6, 3291-3300. [CrossRef]

44. Albareda-Tiana, S.; Vidal-Raméntol, S.; Pujol-Valls, M.; Fernández-Morilla, M. Holistic Approaches to Develop Sustainability and Research Competencies in Pre-Service Teacher Training. Sustainability 2018, 10, 3698. [CrossRef]

(C) 2018 by the authors. Licensee MDPI, Basel, Switzerland. This article is an open access article distributed under the terms and conditions of the Creative Commons Attribution (CC BY) license (http:/ / creativecommons.org/licenses/by/4.0/). 